DOI 10.37882/2500-3682.2021.08.13

\title{
СУБЪЕКТЫ И ТЕХНОЛОГИИ ВОПЛОЩЕНИЯ СИМВОЛИЧЕСКИХ ПРОСТРАНСТВ РОССИИ В УСЛОВИЯХ СТРАТЕГИЧЕСКОЙ НЕСТАБИЛЬНОСТИ
}

\section{SUBJECTS AND TECHNOLOGIES FOR THE EMBODIMENT OF THE SYMBOLIC SPACES OF RUSSIA IN THE CONTEXT OF STRATEGIC INSTABILITY}

\section{N. Latysheva}

Summary: The modern world is distinguished by unparalleled instability and changeability. The reasons and factors of its instability have long been the objects of study and analysis of domestic and foreign researchers. Many scientists distinguish the object-subjective aspects of social fluctuations and shocks. These are, first of all, the globalist intentions of certain world circles and elites. They are reflected in the corresponding cultural trends and symbolic and sign values. In many ways, such actions are associated with the leveling of national consciousness and culture. Often they are directed to depersonalize and discredit them. In the article, the author reveals the specifics of the symbolic spaces of Russia, identifies its main subjects and the technologies they use to embody the symbolic spaces of Russia, taking into account the specifics of modern strategic instability in the world. The author notes that the real unity of Russia is formed initially through the achievement of unity in symbolic spaces through overcoming the threats of strategic instability. Social networks and related technologies are identified as one of the factors of instability in the social space.

Keywords: discourse, subjects of symbolic spaces, symbolic spaces of Russia, symbol, strategic instability, technologies for the embodiment of symbolic spaces.

\author{
Латышева Наталья Александровна \\ К.ф.н., доцент, Российский университет транспорта \\ (МИИТ-РОАТ), \\ nalat59@mail.ru
}

Аннотация: Современный мир отличается беспримерной нестабильностью и изменчивостью. Причины и факторы его неустойчивостью давно являются объектами изучения и анализа отечественных и зарубежных исследователей. Многие ученые выделяют объектно-субъективные аспекты социальных флуктуаций и потрясений. Это, в первую очередь, глобалистские интенции определенных мировых кругов и элит. Они находят отражение в соответствующих культурологических тенденциях и символико-знаковых ценностях. Во многом подобные действия связаны с нивелированием национального сознания и культуры. Часто они направление на их обезличивание и дискредитацию. В статье автор раскрывает специфику символических пространств России, выявляет его основных субъектов и используемые ими технологии воплощения символических пространств России с учетом специфики современной стратегической нестабильности в мире. Автор отмечает, что реальное единство России формируется первоначально через достижение единства в символических пространствах через преодоление угроз стратегической нестабильности. Одним из факторов нестабильности в социальном пространстве определены социальные сети и связанные с ними технологии.

Ключевые слова: субъекты символических пространств, символические пространства России, символ, стратегическая нестабильность, технологии воплощения символических пространств.

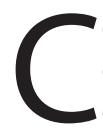
овременный мир характеризуется тотальной нестабильностью. Каждый день мы слышим о кризисе, катастрофах, хаосе, военных конфликтах. А.С. Панарин один из первых в своих работал XXI век распознал и определил, как век стратегической нестабильности: «XXI век только начался, а здесь он уже окрещен в целом как стратегически нестабильный - то есть непредсказуемо пертурбационный в самых существенных моментах» [7, с. 5.]. А.С. Панарин пришел к выводу, что источником нестабильности является бросок ряда элит рыночной цивилизации обмена к своему планетарному доминированию под прикрытием понятиями «глобализация», «глобализм»: «Глобализм» ныне - наимоднейшее слово либерально-прогрессистской мысли. Хотя, если вдуматься в объективное содержание, обозначаемое этим словом, нас поразит его банальность. В самом деле: еще в начале XIX столетия исследователи писали о едином мировом пространстве, создаваемом рыночной цивилизацией обмена... Как бы ни поражала наше воображение современная информационная революция, к сути понятия, обозначающего мировую цивилизацию обмена, она мало чего добавляет». [6, с. 5.]

А.С. Фурсов пишет о кризисе-матрешке, который неразрывно связан с борьбой проектов. [17, с. 3-20] Кризис-матрешка содержит в себе несколько взаимосвязанных кризисов: кризис мультикультурализма, который продвигали сторонники глобализма, демографический кризис, биосферно-экологический. И генерируются эти кризисы капитализмом, самой его природой: «Поскольку капитализм - это, во-первых, глобальная система, вовторых, система, основанная на необратимой эксплуатации не только человека, но и природы, его кризис - это ресурсный кризис в масштабах планеты Земля». [16, с.13.]

Последнее указывает на то, что современный гло- 
бальный хаос и стратегическая нестабильность обусловлены деятельностью определённых социальных субъектов. У этого стратегического хаоса есть определённые выгодополучатели/бенефициары. [18]

Конечно, у современной стратегической нестабильности есть и объективная сторона. Но сама риторика, связанная с ситуацией хаоса и глобальной нестабильности, все жёстче смыкается на человеке, который объявляется главным виновником хаоса. [20]

Следует отметить, что не конкретному человеку, а человеку как таковому, как биологическому типу и форме живого фактически объявлена война и провозглашен курс на постчеловечество и конец истории. [13] Одновременно ведется работа по демонтажу национального государства и основанной на нем архитектуры современного мира. [15] События, связанные с Covid-2019, усиливают данные тенденции. [5]

Удивляют и названия некоторых работ, которые можно рассматривать и как своеобразный симптом происходящего. Примером может служить работа Ф. Фукуямы «Наше постчеловеческое будущее: Последствия биотехнологической революции». [14] Складывается впечатление, что автор работы не является представителем человечества, а неких субъектов, стремящихся выйти за пределы человечества путём его отрицания и преодоления. Ф. Ницше этого субъекта определил, как сверхчеловека.

В этом плане сама технологическая революция выступает источником хаоса и нестабильности, вызывая у людей шок будущего (футурошок), о чём в своё время отметил в своей работе Э. Тоффлер. [11], по его мнению, шок, который испытывают люди, приводит к психологическому онемению, к самой реальной опасности, которая подстерегает человечество. Причина шока будущего - увеличивающийся разрыв между скоростью перемен в разных секторах общества, скоростью изменения окружения и ограниченной скоростью человеческой реакции на эти изменения. [11] Футурошок вызывает культурный шок, который в свою очередь ведет к замешательству, фрустрации, дезориентации и реальным болезням среди больших масс людей. [11]

Применительно к России эта ситуация осложняется определенными циклами разрыва в истории. Н.А. Бердяев указанную особенность русской истории описал следующими образом: «Для русской истории характерна прерывность. В противоположность мнению славянофилов, она менее всего органична. В русской истории есть уже пять периодов, которые дают разные образы. Есть Россия киевская, Россия времен татарского ига, Россия московская, Россия петровская и Россия советская. И возможно, что будет новая Россия». [1, с.15.] Послед- ние 30 лет Россия находится на таком переходе от одной своей исторической формы к другой, которую Н.А. Бердяев назвал «новой».

При этом следует отметить еще одну особенность русской истории. Пристальное внимание за отечественной историей позволяет говорить об определенными циклах падения России по причине сбоя в мировоззрении и целеполагание элиты. Слово о полкуИгореве красноречиво об этом говорит. А в наши дни источником падения России стал мировоззренческий и ценностный соблазн элиты глобализмом. Определённые детали этого процесса описаны А.С. Панариным в соответствующей работе. [6]

Символическое пространство является одним из измерений бытия России, российского общества и государства. И оно также стало одним из пространств стратегической нестабильности. Эти явления идут по всему миру. Ярким выражением данного процесса является снос памятников, которые так или иначе связаны с базовыми идеями и событиями Нового времени. По большому счёту, этот хаос связан с сознательной деконструкцией Модерна как культурно-исторического проекта и фазы развития человечества. Базовым средством-технологией демонтажа Модерна является постмодернизм.

Постмодернизм первоначально возник с сферы искусства, то есть в символическом пространстве. Снос Модерна начался именно в символической сфере: с деконструкции базовых идей и принципов архитектуры Модерна. Феномен и практика постмодерна неразрывно привели к эпохе постправды [16] и тотальности фейков. [12]

Символ изначально имел свою онтологию, он был онтологичен и являлся смысловым и энергийным проводником человека к трансцендентному, метафизическому миру. Символы выступали своеобразными концептами/ зародышами, которые, попадая в благоприятную среду разворачивались в самых разных социальных формах: от отдельного города до целой империи, мир-системы (если, использовать терминологию И. Валлерстайна). На этом строилась вся теория символического реализма как в искусстве, так и в социальном проектировании. [4]

В этой связи, на примере анализа творчества Ф.М. Достоевского Вяч. Иванов в работе «Достоевский: Трагедия - Миф - Мистика» писал: «...Мировоззрение Достоевского предстает как своеобразный онтологический реализм, основывающийся на мистическом проникновении в чужое Я как на некоей реальности, существующей в Ensrealissimum. Художественное исследование причин человеческих действий в трех планах прагматическом, складывающемся из внешних событий, психологическом и, наконец, метафизическом, являю- 
щемся одновременно сферой характера умопостигаемого, - показывает, что человек действует и самоопределяется как совершенно свободная личность только в этом, третьем плане. Тем самым собственно трагедия перемещается в область первичного самоопределения свободной воли, то есть в сферу метафизическую». [3, C. 5-6.]

Постмодернизм разрушает любую онтологию символа, создавая механические и волюнтаристски любой набор символов прошлых эпох без онтологии. Его царство - поверхность, мир дольний. Поэтому и преобладает в постмодернизме формат и феномен ризомы. Об этой угрозе писал в своё время В.С. Соловьев: «Но, чуждые прежнему религиозному содержанию искусства, они обращаются всецело к текущей действительности и ставят себя к ней в отношение рабское вдвойне: они, во-первых, стараются рабски списывать явления этой действительности, а во-вторых, стремятся столь же рабски служить злобе дня, удовлетворять общественному настроению данной минуты, проповедовать ходячую мораль, думая чрез то сделать искусство полезным. Конечно, ни та, ни другая из этих целей не достигается. В безуспешной погоне за мнимо-реальными подробностями только теряется настоящая реальность целого, а стремление соединить с искусством внешнюю поучительность и полезность к ущербу его внутренней красоты превращает искусство в самую бесполезную и ненужную вещь в мире, ибо ясно, что плохое художественное произведение при наилучшей тенденции ничему научить и никакой пользы принести не может». [10, с. 58-59. (с. 57-72).]

В этой ситуации можно выделить два типа субъектов (индивидуальных и коллективных) и связанных с ними технологиями воплощения символических пространств России в условиях стратегической нестабильности.

Первый тип субъектов можно определить, как онтологически укорененных, они и личностно и социально связаны с практиками постижения трансцендентного. Их символ - вертикаль и глубина. Второй тип характеризуется своеволием и жаждой установления своей власти над миром. В определённой степени - это символически показано Рафаэлем в картине «Афинская школа». Первый тип субъектов и субъектности представлен Платоном, второй - Аристотелем. Неспроста Платон считается органически связанным с Востоком, а Аристотель - с Западом.

Первые - субъекты онтологического символизма выстраивают символическое единство народов, племен, земель, эпох и т.п. Вторые - используют технологии распада и разрушения через дискредитацию реальных символов и создание символов симулятивных ложных.
Первые формировали вистории России процесс, который получил название «Собирание земель русских». Вот как этот процесс описывает Ф.К. Шенк: «Церковь под небесным покровительством “премудрости Божией” принадлежала к символическому инвентарю столиц Руси, которые задумывались и концептуализировались как отражения Константинополя или Иерусалима. Софийский собор стал символом Новгорода, в источниках часто именовавшегося "городом Святой Софии" ...». [19, с. 38]

Ф.К. Шенк отмечает: «Прославленный великий князь Александр Ярославич оказался символом, переходившим из рук в руки в борьбе за политическую власть между Москвой и Новгородом. Оба города стремились завладеть историческим и символическим наследством Киевской Руси для утверждения собственных политических амбиций. Конкурирующие дискурсы об Александре Невском в новгородской литературе XV в. - признаки этой борьбы за "русскую историю". Великое княжество Московское с конца XIV в. пыталось подготовить программу "собирания русских земель" посредством "собирания русской истории (или историй)" и символически продолжить ее. Этот процесс выкристаллизовался в летописях, призванных создать представление о единстве земель Руси, и в строительстве символически нагруженных архитектурных сооружений в Московской земле, как и новых новгородских церквей, напоминавших об эпохе единства Русской земли и укреплявших московское самосознание. "Символическая борьба" между Новгородом и Москвой достигла кульминации в конце XV - начале XVI в. в легендарном споре о белом клобуке и шапке Мономаха. Оба головных убора считались репрезентациями регалий правителей византийского происхождения. Ссылаясь на эти легенды, архиепископский двор в Новгороде и связанный с великим князем Московским митрополит претендовали после падения Константинополя в 1453 г. на сакральное наследие Византии». [19, с.76.]

Даже в рамках одного концепта мы можем видеть борьбу различных субъектов за своё первенство в его воплощении. На примере русской истории мы это видим в борьбе Киева и Новгорода за статус Нового Иерусалима или Нового Константинополя. Позже - между Новгородом и Москвой.

Само явление «символической борьбы» не ново для России. Выражением этой символической борьбы в пространстве русской истории являются как историософские концепции в слове, так и архитектурные проекты (философия в камне). В первом случае примером выступает «Слово о законе и благодати» Киевского митрополита Иллариона. Примером «философии в камне» является Десятинный собор в Киеве.

Следует отметить, что поиск форм социально-поли- 
тического единство всегда сопрягается с выработкой форм и концептов такого единства в символическом измерении. Стремление киевского князя Владимира к единству выразилось в создание языческого пантеона на Подоле. Но как показала практика - этот проект уже не соответствовал действительности. В мехи старого языческого мировоззрения не вписывалась смысловая проблематика эпохи и задачи исторического бытия Руси. Поэтому собирание земли Русской происходили на иной мировоззренческой платформе.

Аналогичные процессы происходят и в наши дни. При этом преобладают деструктивные процессы и выстраивание даже символического единства истории России является лишь мечтой. Идет демонтаж советского наследия и демонизация символов. Этот процесс начался со сноса памятника Ф. Дзержинскому на Лубянке и достиг своего определенного апогея на/в Украине. Но одновременно не только на постсоветском пространстве, но и в пределах современной России идет дискредитация символов Императорской России. На Северном Кавказе наблюдается негативны реакция на образы Ермолова, А.В. Суворова. Самым масштабным является критика культурного кода и символики русской/российской цивилизации в целом. Ярким примером является позиция А.И. Ракитова, который в своё время был советником Б.Н. Ельцина. В статье «Цивилизация, культура, технология и рынок» [9. с. 3-15] А.И. Ракитов называет СССР самой большой, самой жестокой империей в истории человечества. [9. с. 3.]

При этом следует отметить, что субъекты-демонтажники символического пространства России вписаны в структуры внешнего субъекта, в структуры субъектов глобализации. Получается двуединый субъект. Этот субъект на символическом уровне по всему миру демонтирует символические структуры образы национальных государств, которые является неотъемлемыми структурами Нового времени и индустриальной фазы развития. Россия в этом отношении особо уязвима, так как народ и элита оказались оторванными друг от друга. [9]

Развитие России в современных условиях требует формирования и усиления коллективного субъекта, способного создать символическое и реальное единство России. Для этого необходимы созидательные технологии и в сфере сознания, в символическом пространстве.

\section{ЛИТЕРАТУРА}

1. Бердяев Н.А. Самопознание: Сочинения. М.: ЗАО Изд-во ЭКСМО-Пресс; Харьков: Изд-во Фолио, 1999. 624 с.

2. Врач назвал признак, подтверждающий, что коронавирус - биологическое оружие // https://rossaprimavera.ru/news/20a759c6

3. Иванов В.И. Достоевский: Трагедия - Миф - Мистика. СПб.: Издательство «Пушкинский Дом», 2021. 476 с.

4. Лосев А.Ф. Проблема символа и реалистическое искусство. М.: РусскійМіръ, 2014. 736 с.

5. Никулин И. Кому и для чего нужна мировая пандемия? Размышление эксперта по биооружию // https://rossaprimavera.ru/article/92fe2b87;

6. Панарин А.С. Искушение глобализмом. М.: Изд-во Эксмо, 2003. 416 с.

7. Панарин А.С. Стратегическая нестабильность в XXI веке. М.: Алгоритм, 2003. С. 5.

8. Панарин А.С. Народ без элиты. М.: Изд-во Алгоритм, Изд-во Эксмо, 2006. 352 с.

9. Ракитов А.И. Цивилизация, культура, технология и рынок // Вопросы философии. № 5, 1992. С. 3-15.

10. Соловьев В.С. Из речей в память Достоевского // 0 великом инквизиторе: Достоевский и последующие. М.: Молодая гвардия, 1992. С. $57-72$.

11. Тоффлер Э. Шок будущего. М.: 000 «Издательство АСТ», 2001.560 c.

12. Фейки: коммуникация, смыслы, ответственность. Коллективная монография / С.Т. Золян, Н.А. Пробст, Ж.Р. Сладкевич, Г.Л. Тульчинский; под ред. Г.Л. Тульчинского. СПб.: Алетейя, 2021. 288 с.

13. Фукуяма Ф. Конец истории и последний человек. М.: 000 «Издательство АСТ: 3 АО НПП «Ермак», 2004. 588 с.

14. Фукуяма Ф. Наше постчеловеческое будущее: Последствия биотехнологической революции. М.: 000 «Издательство АСТ»: 0 A0 «ЛЮКС», 2004.349 С.

15. Фукуяма Ф. Угасание государственного порядка: научно-популярное издание. М.: Издательство АСТ, 2017. 704 с.

16. Фуллер, С. Постправда: Знание как борьба за власть. М.: Изд. дом Высшей школы экономики, 2021. 368 с.

17. Фурсов А.С. Борьба проектов // На пороге глобального хаоса. Битва за будущее. М.: Книжный мир, 2015. С. 3-20

18. Хозяева и бенефициары глобального хаоса. Как победить в битве за будущее. М.: Книжный мир, 2016. 448 с.

19. Шенк Ф.К. Александр Невский в русской исторической памяти: святой, правитель, национальный герой (1263-2000). М.: Новое литературное обозрение, $2007.592 \mathrm{C}$

20. Эстуллин Д. Трансэволюция. Эпоха разрушения человека. М.: Книжный мир, 2015. 352 с. 